\title{
Ice Cube Irrigation of Potted Phalaenopsis Orchids in Bark Media Does Not Decrease Display Life
}

\author{
Kaylee A. South \\ Department of Horticulture and Crop Science, Ohio Agricultural Research \\ and Development Center, The Ohio State University, 1680 Madison Avenue, \\ Wooster, OH 44691
}

Paul A. Thomas, Marc W. van Iersel, and Cindy Young Department of Horticulture, University of Georgia, 1111 Miller Plant Science Building, Athens, GA 30602

\author{
Michelle L. Jones ${ }^{1}$ \\ Department of Horticulture and Crop Science, Ohio Agricultural Research \\ and Development Center, The Ohio State University, 1680 Madison Avenue, \\ Wooster, $\mathrm{OH} 44691$
}

Additional index words. postharvest, potted flowering plant, home plant care, chilling injury, freezing damage

\begin{abstract}
Phalaenopsis orchids are an increasingly popular potted house plant in the United States. New cultivars have a long display life in home environments, but these epiphytes are often overirrigated by consumers. Irrigating potted Phalaenopsis orchids weekly with ice cubes has been recommended as a simple solution to help consumers, but concern has been raised about whether the ice cubes will cause low temperature damage in these tropical plants. The effect of ice cube irrigation on the display life and quality of four cultivars of potted Phalaenopsis orchids was, therefore, evaluated. Irrigation treatments included weekly application of three ice cubes or the equivalent volume of room-temperature tap water. The longevity of individual flowers and the overall display life of the orchid plants were determined. Monthly measurements determined the volume of leachate in the outer decorative pots after irrigation. The quantum yield of photosystem II ( $\left.\Phi_{\text {PSII }}\right)$ in roots and leaves was evaluated monthly to determine if photosynthetic efficiency was affected by the ice irrigation. The temperature in the orchid bark growing media during irrigation events was recorded, and a programmable antifreeze bath was used to determine the temperature at which damage to PSII was observed in orchid roots. The flower longevity and display life were unaffected by irrigation treatment. In general, the leachate volume over time was the same or lower in ice irrigated orchids compared with those irrigated with the same volume of water. The lowest temperature in the bark media irrigated with ice cubes was $\approx 11^{\circ} \mathrm{C}$, while controlled freezing experiments showed that damage to photosystem II in orchid roots did not occur until bath temperatures were below $-7^{\circ} \mathrm{C}$. The internal temperature of roots in direct contact with ice cubes decreased to around $4^{\circ} \mathrm{C}$. Ice cube irrigation had no detrimental effects on the quality or display life of potted Phalaenopsis orchids growing in bark, demonstrating that ice cubes are a viable method of irrigating these tropical house plants.
\end{abstract}

Orchids are currently the top-selling potted flowering plant in the United States because of their long flower life and compact growth

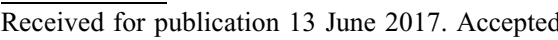
for publication 31 July 2017.

Salaries and research support were provided in part by state and federal funds appropriated to the Ohio Agricultural Research and Development Center, The Ohio State University. Journal Article Number HCS 17-01. Thanks to Green Circle Growers (Oberlin, $\mathrm{OH}$ ) for providing orchids.

We would like to thank Laura Chapin, Eileen Ramsay, Angela Maria Pereira do Nascimento, Courtney Phillips, Sierra McDonald, Grant Laird, and Sue Dove for technical assistance.

${ }^{1}$ Corresponding author. E-mail: jones.1968@osu.edu. This is an open access article distributed under the CC BY-NC-ND license (http://creativecommons. org/licenses/by-nc-nd/4.0/).
(Banks, 2005; Fitch, 2004; USDA, 2016). While the popularity of many potted plants is declining, the number of orchids that are sold each year is increasing. Most commercial orchid sales are Phalaenopsis sp., also called moth orchids (Griesbach, 2002). The USDA Floriculture Crops Summary reported the wholesale value of potted orchids (including Phalaenopsis) to be $\$ 288 \mathrm{mil}$ lion in 2015 , an increase of $\$ 15$ million over the 2014 value (USDA, 2016). The introduction of improved hybrids and the development of large-scale production protocols that reduce the time required to produce flowering plants have allowed potted orchids to be grown for mass-market consumers (Griesbach, 2002).

Phalaenopsis species, which originate from tropical and subtropical climates, have a long flower display life in the typical temperatures and low light levels of a home (Banks, 2005). These orchids are epiphytic in their native environments and grow on trees with their roots exposed to the air (Banks, 2005). The roots of Phalaenopsis orchids contain chlorophyll and are photosynthetic (Dycus and Knudson, 1957; Lopez and Runkle, 2005). Commercial production of Phalaenopsis is usually in a bark-based potting media that allows for good aeration and drainage (Griesbach, 2002). In the home environment, proper irrigation is the largest challenge to maintaining a healthy potted orchid. Underwatering the plant will result in wrinkled, flaccid leaves, whereas overwatering or letting the orchid sit in water can result in damaged roots (Cullina, 2004). Healthy roots of Phalaenopsis are vivid green when the plant is well-watered, and they have a silvery hue when dry. Unhealthy roots are tan or brown (Cullina, 2004).

The technique of irrigating Phalaenopsis orchids with ice cubes has been recommended to orchid owners to reduce the likelihood of over- or underwatering the plants (Onofrey, 2009). Ice cubes provide a convenient way to apply a set volume of water, which is released slowly as the ice melts. The idea is that the ice melt will move slowly through the porous bark media, allowing more water to be absorbed by the bark and roots and resulting in less water accumulation in the bottom of pots where it may cause root damage. Concerns about this technique include whether the melting ice will provide enough water for proper plant growth and whether the ice will cause low temperature damage or reduce the display life of the plants (Cullina, 2004).

Even brief exposure to low temperatures can cause chilling injury $(\mathrm{CI})$ in tropical species (Wang, 2007). Mesophyll cell collapse is a physiological disorder that can occur in orchid leaves exposed to low air or water temperatures (Cating and Palmateer, 2009; Sheehan, 2002). Symptoms include the development of sunken, light-green to yellow areas on the upper surfaces of the leaves, which then turn brown and necrotic. The severity of the CI is dependent on the temperature, duration of exposure, and physiological age of the leaves (McConnell and Sheehan, 1978). Exposure to $2{ }^{\circ} \mathrm{C}$ for $8 \mathrm{~h}$ causes mesophyll cell collapse in Phalaenopsis leaves. Water soaked spots on the upper surface of the leaves can be observed $0.5 \mathrm{~h}$ after removal from the chilling temperature treatment and these progress to deeply sunken dark brown spots within 3 weeks (McConnell and Sheehan, 1978).

While CI can be induced in the leaves of some Phalaenopsis species at temperatures below $10{ }^{\circ} \mathrm{C}$, there is no information about root damage or what temperatures the roots experience when plants are irrigated with ice cubes. The objectives of this research were to 1) evaluate the effect of ice cube irrigation on the flower longevity, display life, and quality of potted Phalaenopsis orchids growing in bark; 2) measure the temperature of the bark 
media after irrigating orchids with ice cubes or water; 3 ) determine if there were any visual or physiological symptoms of lowtemperature damage in the roots or leaves of orchids irrigated with ice cubes; 4) identify the temperature at which the photosynthetic apparatus in orchid roots is damaged; and 5) determine the internal temperature of roots that are in direct contact with ice cubes.

\section{Materials and Methods}

Plant material. Potted orchids (Phalaenopsis sp.) were received on 21 Jan. 2016 at the Ohio Agricultural Research and Development Center in Wooster, $\mathrm{OH}$, and on 22 Jan. 2016 at the University of Georgia, Athens, GA. The orchids were transported on a temperature-controlled truck from Green Circle Growers (Oberlin, OH). Plants were growing in a custom bark media $(95 \%$ bark and 5\% sphagnum peatmoss; Oldcastle Lawn and Garden, Columbus, $\mathrm{OH}$ ) in round, $11.5-\mathrm{cm}$ plastic pots ( $700 \mathrm{~mL}$ volume) inside decorative ceramic pots. The orchids were at a market-ready stage with two flower spikes per plant and three to five open flowers on each spike. Four popular commercial cultivars, 699, 322, 386, and 56-100975, were used in all experiments except where noted.

Expt. 1. Evaluating the effects of ice cube irrigation on the quality and display life of potted Phalaenopsis orchids

Experimental set up and environmental conditions. Experiments were conducted at two locations (Wooster, $\mathrm{OH}$ and Athens, GA) in an interior evaluation room set up to simulate an office or home environment. These locations are referred to as $\mathrm{OH}$ and GA, respectively. All windows in the rooms were blocked, and light was provided by fluorescent lights from 8:00 AM to 5:00 PM daily. The average photosynthetic photon flux $(P P F)$ in the room at plant height in $\mathrm{OH}$ was $7.8 \mu \mathrm{mol} \cdot \mathrm{m}^{-2} \cdot \mathrm{s}^{-1}$, and the range was from 3.0 to $12.5 \mu \mathrm{mol} \cdot \mathrm{m}^{-2} \cdot \mathrm{s}^{-1}$ across the room (LI-190R Quantum; LI-COR BioSciences, Lincoln, NE). In GA, the $P P F$ was 6.8 $\mu \mathrm{mol} \cdot \mathrm{m}^{-2} \cdot \mathrm{s}^{-1}$, and the range was 3.7 to 10.0 umol $\cdot \mathrm{m}^{-2} \cdot \mathrm{s}^{-1}$ across the room (LI-190SA; LICOR BioSciences). The plants were blocked to account for the varying $P P F$. The temperature set point in each room was $21^{\circ} \mathrm{C}$. In $\mathrm{OH}$, a relative humidity around $40 \%$ was maintained using a humidifier (Space Saver Evaporative Humidifier Model 831000; Aircare, Little Rock, AZ). The mean relative humidity in GA was $49 \% \pm 9 \%$. The mean room temperature over the entire experiment was $21.2^{\circ} \mathrm{C}$ with a range of 14.5 to $28.7^{\circ} \mathrm{C}$ in $\mathrm{OH}$ (January to July), and a mean of $22.0^{\circ} \mathrm{C}$ and a range of 14.0 to $26.9^{\circ} \mathrm{C}$ in GA (January to May). Temperature and humidity were monitored using a Watchdog (Model 2475 Plant Growth Station; Spectrum Technologies Inc., Plainfield, IL) or a temperature/ humidity data logger (Hobo U12; Onset Computers, Bourne, MA). Fans were used to increase air circulation, and in $\mathrm{OH}$, air samples were collected monthly to measure ethylene levels in the evaluation room using a gas chromatograph (Varian 3800; Agilent, Foster City, CA). Ethylene was not detected during the experiment.

Treatments. Orchids were arranged on tables in a split-plot randomized complete block design that accounted for the gradient in $P P F$. The main-plot effects were irrigation treatment (ice vs. water) arranged in six complete blocks (replicates). The subplot effects were cultivar $(699,322,386$, and 56-100975) arranged randomly within each main-plot. The experiment comprised 48 experimental units (pots) at each location.

The two irrigation treatments included ice cubes or water. Identical ice cube trays filled with tap water were used at both locations to make ice cubes. A preliminary experiment using a weighing lysimeter was used to determine the daily evapotranspiration by each of the four orchid cultivars in the interior evaluation room in GA. All four cultivars showed similar patterns of water loss. The cumulative water loss from the orchids after 1 week was $\approx 80 \mathrm{~mL}$ (data not shown), which is equivalent to the volume of three ice cubes. Orchids, therefore, received either three ice cubes or the equivalent volume of room temperature tap water $(80 \mathrm{~mL})$ on the same day and time once a week. The three ice cubes were evenly distributed on the surface of the media. Ice cubes did contact aerial roots, but contact with leaves was avoided. Any leachate in the pots was poured out of the decorative pots 24 to $48 \mathrm{~h}$ after irrigation. Once a month, the leachate was collected from the decorative pots $24 \mathrm{~h}$ after irrigation to measure the volume.

Flower longevity and display life. A single flower per spike was tagged on the day of flower opening. Flowers at a similar location on the spike were chosen within a cultivar. There were six single plant replicates of the four cultivars $(n=6)$. The two tagged flowers per plant (one per spike) were treated as a subsample. Flower longevity was determined as the number of days from flower opening until the corolla of the flower wilted. Phalaenopsis flower senescence is first visualized when the corolla starts to wilt and then eventually the dried flower abscises. The display life was determined as the number of days from the start of the experiment (when plants were received) until the day the last flower on the plant wilted $(n=6)$.

Orchid bark media temperature after irrigation. In $\mathrm{OH}$, the temperature of the growing media over time was recorded using soil moisture/EC/temperature sensors (GS3; Decagon Devices, Inc., Pullman, WA) and data loggers (Em50; Decagon Devices). Sensors were inserted from the top down into the first $5.5 \mathrm{~cm}$ of the media of five orchids irrigated with ice and five orchids irrigated with water, all from the cultivar 699. The data loggers recorded measurements every 10 min. In GA, type-T thermocouples, connected to a datalogger (CR23X; Campbell Scientific, Logan, UT), were placed in the growing media of six orchids irrigated with ice and six orchids irrigated with water. The thermocouple was placed in the bark $\approx 5 \mathrm{~cm}$ below an aerial root. Temperature data were collected every $5 \mathrm{~min}$ for $3 \mathrm{~h}$ after an irrigation event.

Quantum yield of photosystem II and chlorophyll content. At the beginning of the experiment, the newest-most fully expanded leaf on each orchid was identified and tagged $(n=6)$. This leaf was used for measurements of both quantum yield of photosystem II $(\mathrm{OH})$ and chlorophyll content $(\mathrm{OH}$ and $\mathrm{GA})$ throughout the experiment. Measurements were taken toward the middle of the tagged leaf each month. The quantum yield of photosystem II was measured for both the leaves and the roots using a chlorophyll fluorometer (FluorPen FP 100 MAX; Photon Systems Instruments, Czech Republic) monthly to determine if the ice or water treatments affected photosystem II. For leaf measurements, the chlorophyll fluorometer was held so that the light sensor was on the top surface of the leaf. A single aerial root that was in direct contact with the ice or water during irrigation was chosen, and the quantum yield of photosystem II was measured after all of the ice cubes had melted, $\approx 5 \mathrm{~h}$ after irrigation. The leaf chlorophyll content was also measured each month using a chlorophyll meter (SPAD-502; Konica Minolta Sensing, Inc., Japan or CCM-200 plus; Apogee Instruments, Logan, UT).

Final shoot and root biomass. Orchids were harvested for final dry weight (DW) determination at the end of the display life or when no flowers remained on any of the plants of a single cultivar $(n=6)$. The timing of this harvest varied by cultivar and by location. After the final monthly measurements were taken for that cultivar, the shoots were separated from the root systems with a pruner. The number of leaves per plant was counted and any yellow leaves or symptoms of cold damage were noted $(\mathrm{OH})$. Leaf area per plant was determined with a leaf area meter (LI-3100; LI-COR BioSciences) (GA). Leaves were placed in paper bags, dried in a forced air oven $\left(60{ }^{\circ} \mathrm{C}\right)$, and weighed to determine the total leaf DW per plant. Bark media was washed off the root systems, and roots were then separated into green (live) roots and brown (dead) roots. Live roots and dead roots for each plant were placed in separate paper bags, dried in a forced air oven, and weighed to determine DW.

\section{Expt. 2. Identifying the temperature at which the photosynthetic apparatus in orchid roots is damaged}

Controlled freezing tests. An aerial root section $(\approx 5 \mathrm{~cm}$ long) was taken from four different plants of each cultivar. Initial darkadapted quantum yield of photosystem II was measured with a fluorometer (FluorPen FP100; Photon Systems Instruments). Individual root sections, wrapped in moistened cheese cloth in test tubes, were placed in an antifreeze bath. Control root sections were left at room temperature $\left(28^{\circ} \mathrm{C}\right)$ to determine possible degradation of the photosynthetic apparatus of the roots after severing them 
from the plants. The temperature of the antifreeze bath started at $5{ }^{\circ} \mathrm{C}$ and was programmed to decrease by $2{ }^{\circ} \mathrm{C}$ every hour. Actual bath temperatures and internal root temperatures (see next paragraph for details on root measurements) were monitored using regular and fine-wire thermocouples (Omega Engineering, Stamford, CT), respectively. Quantum yield of photosystem II gives a measurement of the efficiency with which photosystem II uses absorbed light for electron transport. Dark-adapted quantum yield of photosystem II was measured on all root sections every hour until the dark-adapted

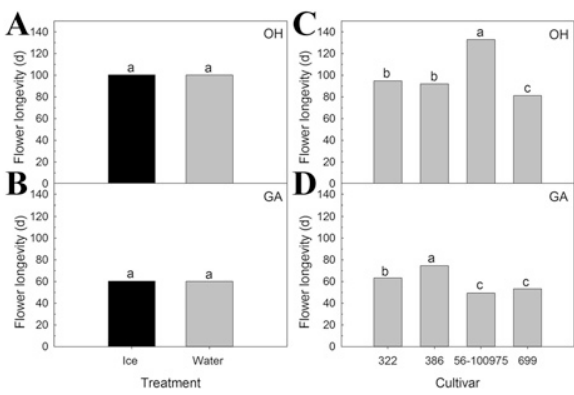

Fig. 1. Flower longevity when Phalaenopsis orchids were irrigated with ice cubes or water. Flower longevity was determined as the number of days from flower opening to flower wilting/senescence measured in $\mathrm{OH}$ (A and C) and GA (B and D). A single flower per spike was selected to monitor the longevity (total of two spikes per plant) on six plants from the ice treatment (black bars) and six plants from the water treatment (gray bars) from each of four cultivars $(322,386,56-100975$, and $699)(n=6)$. Letters indicate significant differences among treatments based on least significant differences test $(P \leq 0.05)$.
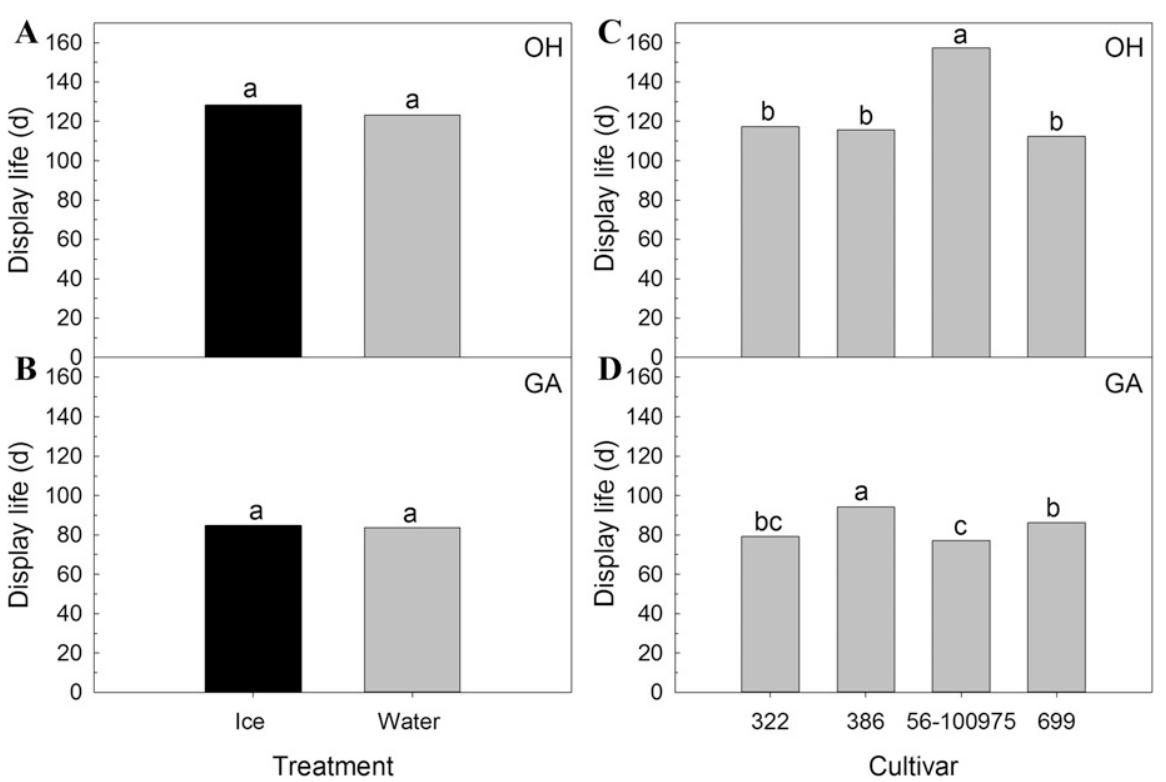

Fig. 2. Display life when Phalaenopsis orchids were irrigated with ice cubes or water. Display life of orchids in $\mathrm{OH}$ (A and $\mathbf{C})$ and GA (B and D) was determined as the number of days from the date the orchids arrived to the date the final flower on each plant wilted. Ice (black bars) or water (gray bars) treatments were applied at the same time weekly to four different cultivars $(322,386,56-100975$, and 699) $(n=6)$. Letters indicate significant differences among treatments based on least significant differences test $(P \leq 0.05)$.

quantum yield declined, indicating damage to photosystem II in the roots $(n=4)$.

\section{Expt. 3. Determining the internal temperature of orchid roots in contact with an ice cube}

Internal root temperature. To determine the effect of ice cubes on the temperature of the stele of the aerial roots, $5-\mathrm{cm}$ long root sections were cut from four different plants of cultivar 699. A fine needle was used to create a hole in the stele of the root. A fine-wire, type-T-thermocouple was then inserted into the stele to measure the internal root temperature. Both ends of the root were sealed with low melting temperature dental wax to prevent dehydration. Data were collected using a data logger (CR10; Campbell Scientific). An ice cube was placed on the root surface, and internal root temperatures were recorded every $5 \mathrm{~min}$ as the ice cube melted $(n=4)$. This experiment was repeated a total of four times. Results are presented for experiment one.

Data analysis. Data were analyzed with Proc GLIMMIX in SAS 9.4 (SAS Institute, Cary, NC). The analysis of Experiment 1 was conducted according to a split-plot design, with irrigation treatment tested using the irrigation treatment $\times$ block effect, and cultivar and the irrigation treatment $\times$ cultivar interaction tested using the residual error. Irrigation treatment, cultivar, and their interaction were considered fixed effects, and block and irrigation treatment $\times$ block were considered random effects. The $F$-test was considered significant at $\alpha=0.05$. Mean comparisons were made using the least significant difference test $(P \leq 0.05)$. The analysis of variance of data from Experiment 2 did not indicate any difference among

HortScience Vol. 52(9) September 2017 cultivars, so data from all cultivars were combined and subsequently analyzed by fitting an exponential rise to a maximum curve to the data (SigmaPlot 11; Systat, San Jose, CA)

\section{Results}

Expt. 1. Evaluating the effects of ice cube irrigation on the quality and display life of potted Phalaenopsis orchids

Flower longevity and display life. Orchid flower longevity was unaffected by irrigation treatment at either location $(\mathrm{OH}, P=0.999$ and GA, $P=0.959$ ) (Fig. $1 \mathrm{~A}$ and $\mathrm{B}$ ). The mean flower longevity in $\mathrm{OH}$ was $100 \mathrm{~d}$ for both the ice- and water-irrigated orchids. In $\mathrm{GA}$, the ice and water irrigation treatments had a mean flower longevity of $60 \mathrm{~d}$. There were no significant irrigation treatment $x$ cultivar interactions $(\mathrm{OH}, P=0.977$ and GA, $P=0.110$ ). The display life of the plants, which was determined as the number of days from arrival until the last flower on the plant wilted, also showed no irrigation treatment effect $(\mathrm{OH}, P=0.304$ and $\mathrm{GA}, P=0.732)$ (Fig. 2A and B) or irrigation treatment $x$ cultivar interaction $(\mathrm{OH}, P=0.511$ and GA, $P=0.542)$. As expected, differences in flower longevity $(\mathrm{OH}, P<0.0001$ and GA, $P<0.0001$ ) (Fig. 1C and D) and display life $(\mathrm{OH}, P<0.0001$ and GA, $P=0.0005)$ were observed among the cultivars (Fig. 2C and D).

Leachate volume and water use. Leachate was collected once a month and measured from each plant at $24 \mathrm{~h}$ after irrigation to determine the volume of water that was not taken up by the plant, but ran through the bark and accumulated in the bottom of the ceramic pot (Figs. 3 and 4). In $\mathrm{OH}$, there was a significant interaction between irrigation treatment and cultivar in all six measurement months $(0.0045 \leq P \leq 0.13)$. Irrigation treatments were, therefore, compared within a single cultivar. For cultivar 322 , there was no difference in leachate volume between irrigation treatments, but the leachate volumes from cultivar 386 were significantly lower with ice cube irrigation compared with water irrigation in all six months. Cultivar 56-100975 had a significantly lower leachate volume for ice cube-irrigated orchids in the first 5 months. Orchids of cultivar 699 had a higher average leachate volume for ice cube-irrigated orchids only in the last measurement month (Fig. 3D). At the GA location, no irrigation treatment $\times$ cultivar interaction was found, so only the irrigation treatment main effects are reported. An irrigation treatment effect was observed in months one $(P=0.0193)$, three $(P=0.0007)$, and four $(P=0.0038)$, with ice cubeirrigation resulting in a lower leachate volume than water-irrigated orchids (Fig. 4).

Media temperatures. In $\mathrm{OH}$, five probes per irrigation treatment were averaged for a single irrigation event in June to measure the media temperature changes after irrigation with water or ice cubes. The average media temperature remained between 20.2 

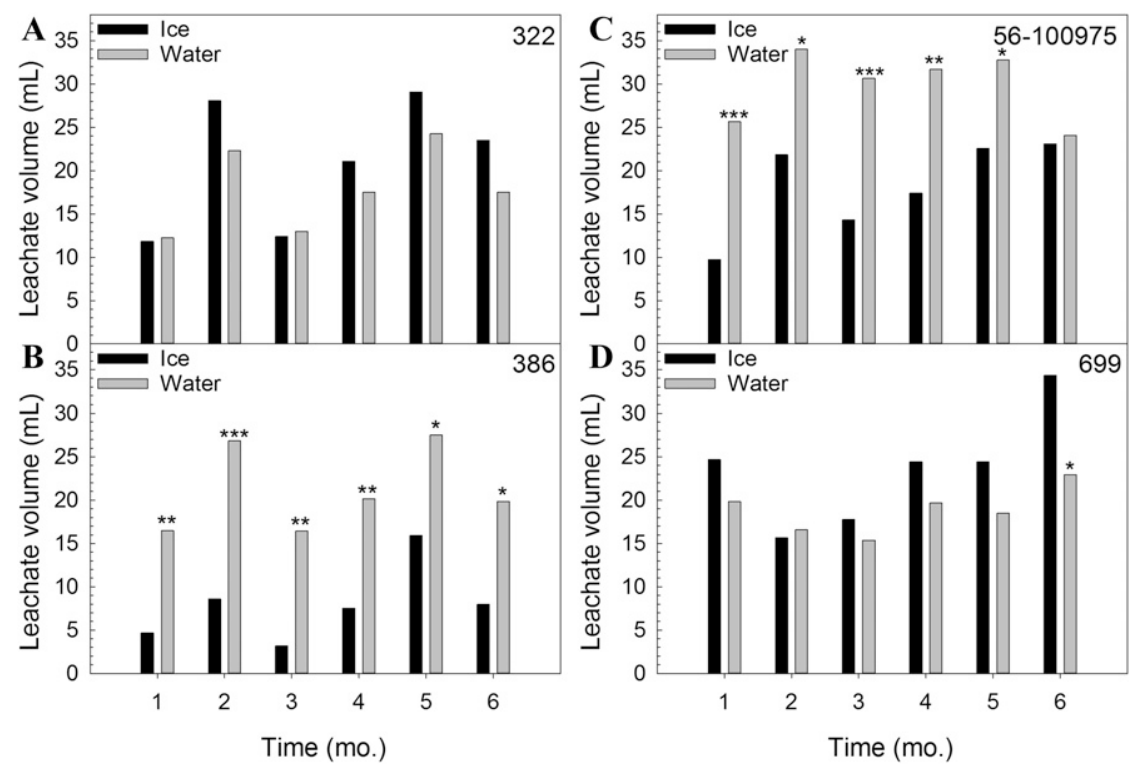

Fig. 3. Leachate volume measured $24 \mathrm{~h}$ after the irrigation of Phalaenopsis orchids in bark media with ice cubes or water in $\mathrm{OH}$. The leachate was collected once a month for 6 months. Irrigation treatments were applied at the same time weekly to four different cultivars $(322,386,56-100975$, and 699) $(n=6)$. The average leachate volume $(\mathrm{mL})$ for the irrigation method, ice cube (black bars) and water (gray bars), is compared within each cultivar for each month. The asterisks indicate significance between the irrigation treatments for a single month; * **, *** significant at $P \leq 0.05,0.01$, or 0.001 , respectively.

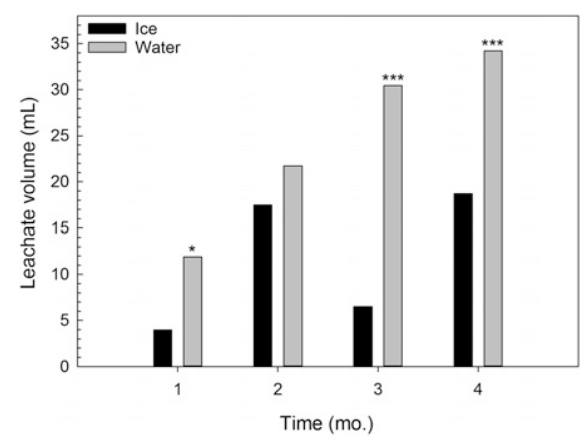

Fig. 4. Leachate volume measured $24 \mathrm{~h}$ after the irrigation of Phalaenopsis orchids in bark media with ice cubes or water in GA. The leachate was collected once a month for 4 months. Irrigation treatments were applied at the same time weekly. The average leachate volume $(\mathrm{mL})$ (mean for four cultivars and six replication), for ice cube (black bars) and water (gray bars), is compared within each month The asterisks indicate significance between the irrigation treatments for a single month; *,**, *** significant at $P \leq 0.05,0.01$, or 0.001 , respectively.

and $21.3^{\circ} \mathrm{C}$ after irrigation with room temperature water (Fig. 5A). Immediately following ice cube irrigation, temperatures in the bark decreased, with the lowest average temperature at $13.6{ }^{\circ} \mathrm{C}$. The media temperature returned to the initial temperature of $21^{\circ} \mathrm{C} 5 \mathrm{~h}$ after ice application. In GA, the average lowest temperature in the bark media with ice cube irrigation was $11.0{ }^{\circ} \mathrm{C}$ (Fig. 5B). Root zone temperatures during other recorded irrigation events showed similar trends.
Quantum yield of photosystem II. The quantum yield of photosystem II of the leaves and roots was monitored monthly over a 5 -month period from the orchids at the $\mathrm{OH}$ location (Table 1). There were no irrigation treatment $\times$ cultivar effects on leaf $(P \geq$ $0.075)$ or root $(P \geq 0.151)$ quantum yield of photosystem II, so the cultivars were combined when comparing the two irrigation treatments. The orchid leaves $(P \geq 0.066)$ and roots $(P \geq 0.076)$ were unaffected by irrigation treatment over the 5 months.

Final harvest. Orchids were destructively harvested to determine the plant biomass at the end of the display life, after all the flowers within a cultivar had wilted. At the termination of the experiment in both locations, all leaves were dark green with no signs of discoloration or water soaking due to chilling or freezing damage. Leaf count, leaf area, and leaf DW were taken as measures of plant health. Leaf count in $\mathrm{OH}$ showed no significant irrigation treatment $\times$ cultivar interaction $(P=0.606)$, and no main effect of irrigation treatment $(P=0.501)$ was found. Leaf area in GA showed no significant irrigation treatment $\times$ cultivar interaction $(P=0.887)$, and the irrigation treatment had no effect $(P=$ 0.179 ) on leaf area (data not shown). In $\mathrm{OH}$, leaf DW showed an irrigation treatment $x$ cultivar interaction $(P=0.025)$ (Table 2$)$. Because of this, irrigation treatments were compared within each cultivar. Cultivar 322 receiving water irrigation had a $0.89 \mathrm{~g}$ higher leaf DW compared with ice irrigation $(P=$ 0.018 ). No effect due to irrigation treatment was found within the other cultivars $(P>0.097)$. In $\mathrm{GA}$, the leaf DW of orchids was unaffected by irrigation treatment $(P=0.191)$ (Table 3$)$.
After leaf harvest, roots were separated into live, green roots and dead, and brown roots so that DW could be determined. In $\mathrm{OH}$, a significant irrigation treatment $\times$ cultivar interaction was found for live root $\mathrm{DW}$, so irrigation treatments were compared within each cultivar $(P=0.018)$. Live root DW of water-irrigated plants of cultivar 699 was $2.24 \mathrm{~g}$ higher compared with that of iceirrigated plants $(P=0.002)$. No effect due to irrigation treatment was found within the other cultivars $(P \geq 0.188)$ (Table 2$)$. The GA live root DW $(P=0.156)$ and dead root $\mathrm{DW}$ at both locations $(\mathrm{OH}, P=0.922$ and GA, $P=0.465$ ) showed no significant differences between the two irrigation methods (Table 3).

Expt. 2. Identifying the temperature at which the photosynthetic apparatus in orchid roots is damaged

Quantum yield of photosystem II as an indicator of low temperature damage in roots. While the temperature of the antifreeze bath was lowered, the internal root temperatures were monitored, and the dark-adapted quantum yield of photosystem II was measured as an indicator of damage. The internal temperature of the roots (cultivar 699) decreased from 7 to $-8{ }^{\circ} \mathrm{C}$ as the bath temperature was reduced from 4.7 to $-8.7{ }^{\circ} \mathrm{C}$ (Fig. 6A). Spikes in the root internal temperature were detected when the internal root temperatures reached -3.8 to $-4.0{ }^{\circ} \mathrm{C}$, indicating an exothermic energy release during the freezing of the water within the roots. There were no differences among the roots of the different cultivars (data not shown). The dark-adapted quantum yield of photosystem II of the orchid root segments declined rapidly when the bath temperatures dropped below $-7^{\circ} \mathrm{C}$ and the internal root temperature was about $-4^{\circ} \mathrm{C}$ (Fig. 6B), which is consistent with the bath temperatures at which the exothermic energy release was seen.

\section{Expt. 3. Determining the internal} temperature of orchid roots in contact with an ice cube

Internal root temperature. Thermocouples inserted into the stele of orchid root segments (cultivar 699) monitored the actual root temperature when roots were in direct contact with a melting ice cube (Fig. 7). The internal temperature of the roots dropped to $4.6{ }^{\circ} \mathrm{C}$ within $15 \mathrm{~min}$ and then gradually increased. Similar patterns were seen in two subsequent runs, but with minimum root temperatures reaching 3.1 and $3.3{ }^{\circ} \mathrm{C}$ (data not shown).

\section{Discussion}

Phalaenopsis orchids are marketed as interior potted plants, and their popularity is based on their long flower life and an overall floral display that can last from 3 to 6 months in the home environment (Blanchard and Runkle, 2006). Under our simulated interior environment, flower longevity and overall display life were similar between ice 

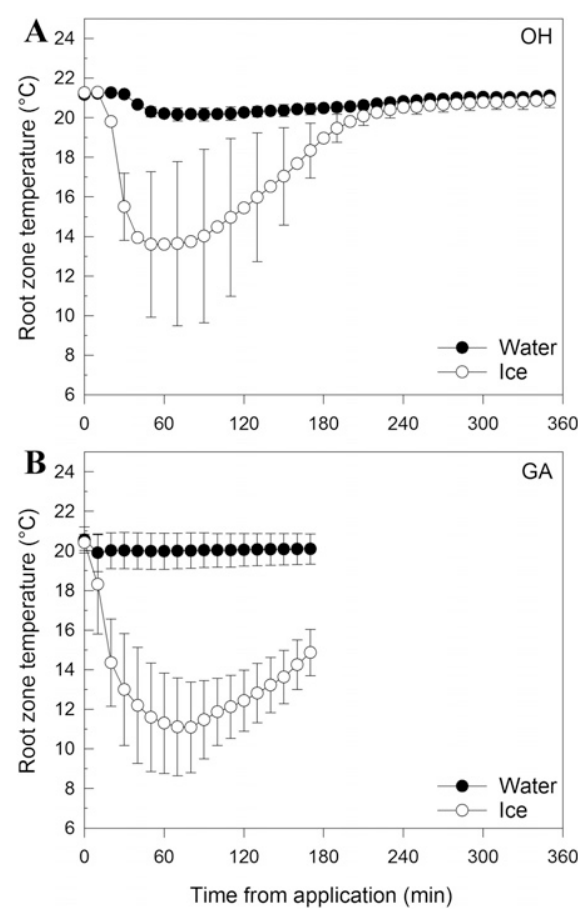

Fig. 5. Temperature of the bark media during irrigation of Phalaenopsis orchids with ice cubes or water. In OH, GS3 probes (Decagon Devices, Inc.) were inserted into the bark media to monitor the temperature in the top $5.5 \mathrm{~cm}$ of the root zone (A). Temperature was monitored in cultivar 699 from five plants treated with ice cubes and five plants treated with water $(n=5)$. The average temperature data are presented for an irrigation event on 27 June 2016 that was representative of other irrigation events monitored over the course of the experiment. In GA, type-T thermocouples, connected to a data logger (CR23X; Campbell Sci.) were used to monitor media temperature in six orchid plants (cultivar 699) irrigated with ice cubes and six orchids irrigated with water $(\mathbf{B})(n=6)$. Thermocouples were placed in the bark, $5 \mathrm{~cm}$ below the aerial roots. The average temperature data are presented for an irrigation event on 4 Mar. 2016. Plants were irrigated with three ice cubes (open circle) or the equivalent volume of room temperature water (solid circle) weekly. Vertical bars indicate standard deviation.

Table 1. Quantum yield of photosystem II of leaves and roots of Phalaenopsis orchids in bark media irrigated with ice cubes or water at the Ohio $(\mathrm{OH})$ location. Measurements were taken once a month for 5 months.

\begin{tabular}{llr}
\hline \multirow{2}{*}{$\begin{array}{ll}\text { Time } \\
\text { (mo.) }\end{array}$} & \multicolumn{1}{c}{ Ice $^{\mathrm{z}}$} & Water \\
\cline { 2 - 3 } & \multicolumn{2}{l}{ Leaf-Quantum yield of PSII } \\
\hline 1 & $0.80 \mathrm{a}^{\mathrm{y}}$ & $0.80 \mathrm{a}$ \\
3 & $0.79 \mathrm{a}$ & $0.79 \mathrm{a}$ \\
4 & $0.80 \mathrm{a}$ & $0.79 \mathrm{a}$ \\
5 & $0.80 \mathrm{a}$ & $0.79 \mathrm{a}$ \\
& $0.79 \mathrm{a}$ & $0.79 \mathrm{a}$ \\
& \multicolumn{3}{l}{} \\
\hline 1 & \multicolumn{2}{l}{ Root-Quantum yield of PSII } \\
2 & $0.68 \mathrm{a}$ & $0.71 \mathrm{a}$ \\
3 & $0.64 \mathrm{a}$ & $0.67 \mathrm{a}$ \\
4 & $0.69 \mathrm{a}$ & $0.65 \mathrm{a}$ \\
5 & $0.67 \mathrm{a}$ & $0.55 \mathrm{a}$ \\
\hline & $0.63 \mathrm{a}$ & $0.47 \mathrm{a}$ \\
\hline
\end{tabular}

${ }^{\mathrm{z}}$ Ice or water irrigation was applied weekly.

${ }^{\mathrm{y}}$ Means are compared within a single row $(n=6)$ and means with different letters are significantly different at $P \leq 0.05$.

Table 2. Final dry weight (DW) measurements of leaves, live roots, and dead roots of Phalaenopsis orchids grown in bark media in $\mathrm{OH}$ irrigated with either ice cubes or the equivalent amount of room temperature water.

\begin{tabular}{|c|c|c|c|c|}
\hline \multirow[b]{3}{*}{ Cultivar } & \multicolumn{2}{|c|}{ Irrigation treatment } & \multirow[b]{2}{*}{$P$ value } & \multirow[b]{2}{*}{ Significance $^{y}$} \\
\hline & Ice & Water & & \\
\hline & \multicolumn{4}{|c|}{ Leaf dry wt (g) } \\
\hline 322 & $5.20^{2}$ & 6.09 & 0.018 & $*$ \\
\hline 386 & 4.69 & 5.16 & 0.194 & \\
\hline $56-100975$ & 4.96 & 4.41 & 0.134 & \\
\hline \multirow[t]{2}{*}{699} & 4.44 & 5.05 & 0.097 & \\
\hline & \multicolumn{4}{|c|}{ Live root DW (g) } \\
\hline$\overline{322}$ & 3.71 & 4.61 & 0.188 & \\
\hline 386 & 5.44 & 5.33 & 0.867 & \\
\hline $56-100975$ & 4.94 & 4.13 & 0.235 & \\
\hline \multirow[t]{2}{*}{699} & 2.88 & 5.12 & 0.002 & $* *$ \\
\hline & \multicolumn{4}{|c|}{ Dead root DW $(\mathrm{g})$} \\
\hline All cultivars & 1.02 & 1.01 & 0.922 & \\
\hline
\end{tabular}

${ }^{\mathrm{z}}$ Means are compared within a single row $(n=6)$.

${ }^{\mathrm{y}}$ Significance is indicated by $* * *$, or $* * *$ at $P \leq 0.05,0.01$, or 0.001 , respectively.

Table 3. Final dry weight (DW) measurements of leaves, live roots, and dead roots of Phalaenopsis orchids grown in bark media in GA irrigated with either ice cubes or the equivalent amount of room temperature water.

\begin{tabular}{|c|c|c|c|c|}
\hline \multirow[b]{2}{*}{ Dry wt (g) } & \multicolumn{2}{|c|}{ Irrigation treatment } & \multirow[b]{2}{*}{$P$ value } & \multirow[b]{2}{*}{ Significance } \\
\hline & Ice & Water & & \\
\hline Leaf & $4.31^{y}$ & 4.67 & 0.191 & \\
\hline Live root & 4.49 & 5.07 & 0.156 & \\
\hline Dead root & 0.80 & 0.92 & 0.465 & \\
\hline
\end{tabular}

${ }^{\mathrm{z}}$ Significance is indicated by $*, * *$, or $* * *$ at $P \leq 0.05,0.01$, or 0.001 , respectively.

${ }^{\mathrm{y}}$ Means are compared within a single row $(n=6)$.

cube- and water-irrigated plants (Figs. 1 and 2). Flower loss from bud abscission and abnormal flower opening may be observed if flowers are exposed to extreme temperature stress (Cullina, 2004; Lopez and Runkle, 2005). Tracking the opening and wilting of individual flowers daily also allowed us to observe the overall quality of the flowers. No premature flower loss or abnormal flower development was observed in either the ice or water treatment. These experiments confirmed that ice irrigation did not have a negative impact on flower or plant quality.

Overall plant health and display life depends on proper irrigation. Irrigation instructions are not easy to give to beginning orchid owners, and the symptoms of overwatering can look similar to those of underwatering (Cullina, 2004). Consistent irrigation in the form of three ice cubes per week, rather than a measured volume of water, is a simpler, more convenient technique for consumers. The media used for the production of most commercial Phalaenopsis orchids consists of very coarse bark, and applied water drains very quickly (Griesbach, 2002). The volume of leachate was either the same, or in some irrigation events, it was greater in orchids irrigated with room temperature water compared with those irrigated with ice cubes. The slower release of water from ice cubes can allow for an increased uptake of water by the plant or greater retention within the media. The accumulation of leachate in the pots can lead to significant root damage (Cullina, 2004), and the extent of this damage is influenced by the sensitivity of the specific cultivar. In our interior evaluation room, the water use by the orchids and loss from media evaporation, as determined by a lysimeter experiment, was $\approx 80 \mathrm{~mL}$ per week. This is equivalent to the volume of three ice cubes. The water needs of potted orchids will vary based on seasonal temperature, light, and relative humidity changes in the home, and consumers may need to increase or decrease the number of ice cubes that are applied. Regular monitoring of media moisture will still be needed (Cullina, 2004).

The primary concern that has been raised about irrigating with ice cubes is that it may cause low temperature injury in these cold sensitive tropical orchids. Leaf mesophyll cell collapse is a physiological disorder in orchids that is caused by cold temperatures (Cating and Palmateer, 2009). The symptoms of $\mathrm{CI}$ in the leaves are visualized as sunken, yellow, water-soaked spots on the upper leaf surface that progress into brown necrotic spots (McConnell and Sheehan, 1978). Temperatures below $10^{\circ} \mathrm{C}$ result in mesophyll cell collapse in Phalaenopsis leaves (McConnell and Sheehan, 1978). Growers have seen these symptoms at low production temperatures, and damage also occurs when orchid plants are exposed to low temperatures during shipping (Wang, 2007). In a preliminary experiment with Phalaenopsis orchids, ice cubes applied directly to the leaves resulted in the formation of water soaked spots (data not shown), but the recommendation for ice irrigation is to avoid placing the ice cubes directly on or against the leaves. In the current research, ice cubes were placed on the surface of the 

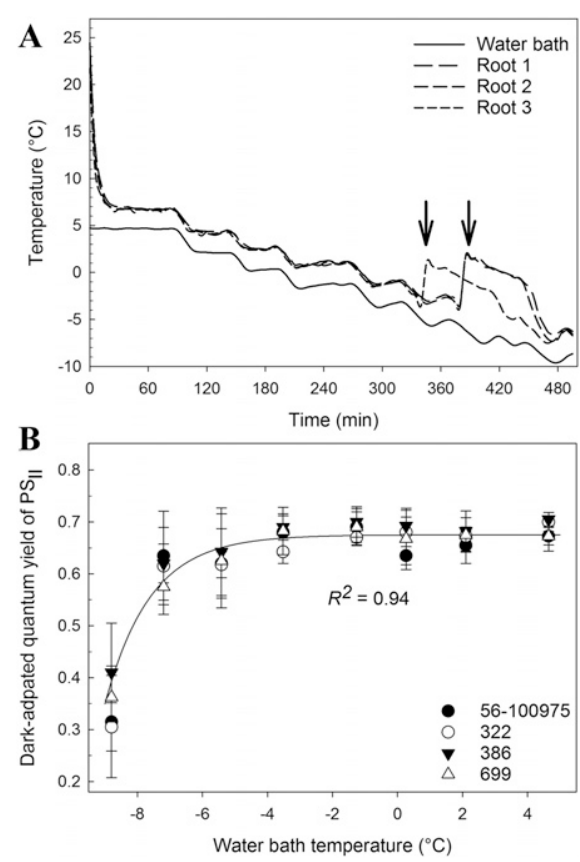

Fig. 6. Low temperature effects on internal root temperature and dark-adapted quantum yield of photosystem II in Phalaenopsis roots. Orchid root segments were placed in a programmable antifreeze bath, and the temperature was decreased by $2{ }^{\circ} \mathrm{C}$ every hour. Fine-wire thermocouples inserted into the stele of the root monitored the internal root temperature as the bath temperature decreased. Three individual root segments from cultivar 699 are represented by the three dashed lines and the bath temperature is represented by the solid line (A). The exothermic energy released during the freezing of the water within the roots is indicated by the arrows. The dark-adapted quantum yield of photosystem II of root segments was measured each hour. Symbols represent the four cultivars, and the vertical bars indicate standard deviation $(n=4)(\mathbf{B})$. The exponential rise to a maximum curve was fitted through the combined data that can be represented by the equation, Dark - adapted quantum yield of photosystem $\mathrm{II}=0.647+0.000114 \times\left(1-e^{(-0.904 \times \text { temp })}\right)$.

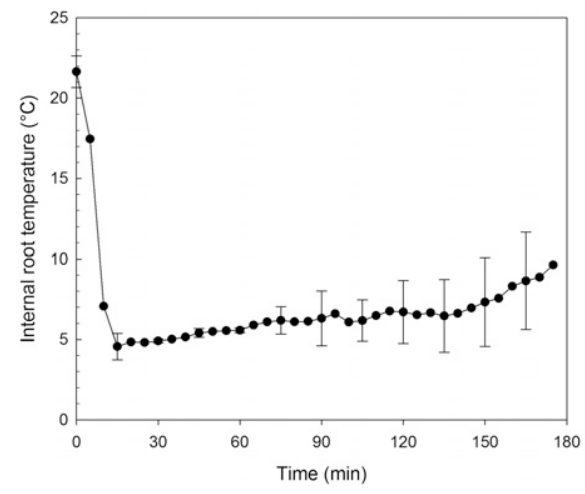

Fig. 7. Internal temperature when Phalaenopsis orchid roots were in direct contact with ice. Ice cubes were applied at time zero to root segments (cultivar 699) that had a fine-wire thermocouple inserted into the stele of the root. The line represents the average internal root temperature, and vertical bars indicate standard deviation $(n=4)$. bark media. There was adequate space in all cultivars to avoid direct contact with the leaves. We did not observe symptoms of leaf mesophyll cell collapse in any of the cultivars at either location.

Chlorophyll fluorescence has been used as a physiological indicator of both chilling and freezing injury (Forney et al., 2000; Lurie et al., 1994; Maxwell and Johnson, 2000). Chlorophyll fluorescence measurements provide a nondestructive measure of quantum yield of photosystem II, which is sensitive to a range of environmental stresses, including cold (Maxwell and Johnson, 2000; Murchie and Lawson, 2013). These measurements showed no indication of chilling damage in the leaves of orchids that were irrigated with ice (Table 1). With the exception of a small increase in the average shoot DW of cultivar 322 orchids in $\mathrm{OH}$ irrigated with water, the final DWs, leaf counts, and leaf areas showed that the foliage of ice-irrigated orchids was as healthy as the foliage of water-irrigated orchids (Tables 2 and 3, and data not shown).

Phalaenopsis orchids have photosynthetic aerial roots covered with a spongy tissue comprising layers of dead cells called the velamen (Dycus and Knudson, 1957; Lopez and Runkle, 2005). During ice irrigation, aerial roots were often in direct contact with the ice cubes, and the roots in the bark media were in contact with the ice melt. Aerial roots that were in direct contact with ice showed no evidence of damage to the photosynthetic apparatus as determined by the monthly chlorophyll fluorescence measurements (Table 1). Thermocouples in the media were used to monitor the temperatures experienced by the roots within the top quarter of the media volume during many irrigation events throughout the 6 months of the experiment. Chilling temperatures between 0 and $15{ }^{\circ} \mathrm{C}$ can result in growth retardation, inhibition of photosynthesis, discoloration or lesions on the leaves, and leaf senescence or abscission in tropical species (Lyons, 1973). Less is known about CI in the roots. In this experiment, the bark temperature during ice irrigation decreased to a minimum temperature around $14{ }^{\circ} \mathrm{C}$ in $\mathrm{OH}$ and $11{ }^{\circ} \mathrm{C}$ in GA and returned to room temperature within $5 \mathrm{~h}$ (Fig. 5). In Phalaenopsis aphrodite plants, the growth rate of the white, nonvelamentous root tips decreased after $8 \mathrm{~h}$ of exposure to $4{ }^{\circ} \mathrm{C}$, and they showed some withering by $12 \mathrm{~h}$ (Peng et al., 2014). The final harvest data in our experiment indicated that root health was not impacted by the irrigation treatment (Table 2). Phalaenopsis cultivars react differently to environmental and cultural practices. The differences in live root DW (OH only) are an example of such cultivar differences. Cultivar 699 waterirrigated orchids had higher live root DW than that of ice-irrigated orchids, while no differences were observed in the other cultivars. While the irrigation treatment may have had an effect on the growth of roots in cultivar 699 , there was no difference in the $\mathrm{DW}$ of the dead roots between the ice and water treatments in this cultivar.
Experiments using an antifreeze bath did not show any effects on the quantum yield of photosystem II in orchid root segments after short-term exposure to chilling temperatures (above $0{ }^{\circ} \mathrm{C}$ ), but inhibition of quantum yield of photosystem II was observed when bath temperatures dropped below $-7{ }^{\circ} \mathrm{C}$ and root temperatures were about $-4{ }^{\circ} \mathrm{C}$ (Fig. 6). This is well below the temperatures that could be caused by irrigating potted Phalaenopsis orchids with ice cubes because placing ice cubes directly on root sections did not cause internal root temperatures to drop below $3{ }^{\circ} \mathrm{C}$ (Fig. 7). While damage could be cumulative over the months of irrigation, our experiments also showed that at each irrigation event it only took $5 \mathrm{~h}$ for the root zone temperature to return to the initial temperature (Fig. 5).

Irrigating using ice cubes provides a viable solution to help orchid owners maintain healthy potted Phalaenopsis orchids and prevent over- or underwatering. Three ice cubes were sufficient in our low light, interior evaluation room, but this will vary based on changes in environmental conditions, and consumers should be encouraged to monitor the moisture levels in the bark and to watch for symptoms of underwatering, including wrinkled leaves and darker silver-colored roots (Cullina, 2004). Even with ice irrigation, which limits the volume of water that is applied, the remaining leachate in the bottom of any decorative pots should be poured out to prevent roots from sitting in water and allow them to get adequate oxygen. While ice cube irrigation causing low temperature damage in tropical plants is a valid concern, we found that irrigating Phalaenopsis orchids grown in $95 \%$ bark potting media with ice cubes or room temperature water resulted in high quality plants with excellent flower longevity and display life.

\section{Literature Cited}

Banks, D.P. 2005. Orchid grower's companion: Cultivation, propagation, and varieties. Timber Press, Portland, OR.

Blanchard, M.G. and E.S. Runkle. 2006. Temperature during the day, but not during the night, controls flowering of Phalaenopsis orchids. J. Expt. Bot. 57:4043-4049

Cating, R. and A. Palmateer. 2009. Physiological disorders in orchids: Mesophyll cell collapse. Univ. of Florida, Coop. Ext. Serv. PP265.

Cullina, W. 2004. Understanding orchids: An uncomplicated guide to growing the world's most exotic plants. Houghton Mifflin, Boston, NY.

Dycus, A.M. and L. Knudson. 1957. The role of the velamen of the aerial roots of orchids. Bot. Gaz. 119:78-87.

Fitch, C.M. (ed.). 2004. The best orchids for indoors. Brooklyn Botanic Garden, Brooklyn, NY

Forney, C.F., M.A. Jordan, K.U.K.G. Nicholas, and J.R. DeEll. 2000. Volatile emissions and chlorophyll fluorescence as indicators of freezing injury in apple fruit. HortScience 35:12831287.

Griesbach, R.J. 2002. Development of Phalaenopsis orchids for the mass-market, p. 458-465. In: J. Janick and A. Whipkey (eds.). Trends in new crops and new uses, ASHS Press, Alexandria, VA. 
Lopez, R.G. and E.S. Runkle. 2005. Environmental physiology of growth and flowering of orchids. HortScience 40:1969-1973.

Lurie, S., R. Ronen, and S. Meier. 1994. Determining chilling injury induction in green peppers using nondestructive pulse amplitude modulated (PAM) fluorometry. J. Amer. Soc. Hort. Sci. 199:59-62.

Lyons, J.M. 1973. Chilling injury in plants. Annu. Rev. Plant Physiol. 24:445-466.

Maxwell, K. and G.N. Johnson. 2000. Chlorophyll fluorescence - a practical guide. J. Expt. Bot. 51:659-668.
McConnell, D.B. and T.J. Sheehan. 1978. Anatomical aspects of chilling injury to leaves of Phalaenopsis B1. HortScience 13:705-706

Murchie, E.H. and T. Lawson. 2013. Chlorophyll fluorescence analysis: A guide to good practice and understanding some new applications. J. Expt. Bot. 64:3983-3998.

Onofrey, D. 2009. Driving sales and value. Greenhouse Grower. 29 Oct. 2009. <http://www. greenhousegrower.com/uncategorized/drivingsales-value/>.

Peng, P.H., C.H. Lin, H.W. Tsai, and T.Y. Lin. 2014. Cold response in Phalaenopsis aphrodite and characterization of PaCBF1 and PaICE1. Plant Cell Physiol. 55:1623-1635.

Sheehan, T. 2002. Physiological disorders of orchids. In: Orchid pests and diseases, revised edition. American Orchid Society, Delray Beach, FL.

U.S. Department of Agriculture (USDA). 2016. Floriculture crops 2015 summary. U.S. Dept. Agr., Washington, D.C.

Wang, Y.T. 2007. Temperature, duration in simulated shipping, and thermal acclimatization on the development of chilling injury and subsequent flowering of Phalaenopsis. J. Amer. Soc. Hort. Sci. 132:202-207. 